Review

\title{
Cyclophilins as Modulators of Viral Replication
}

\section{Stephen D. Frausto, Emily Lee and Hengli Tang *}

Department of Biological Science, The Florida State University, Tallahassee, FL 32306, USA; E-Mails: sfrausto@bio.fsu.edu (S.D.F); elee@bio.fsu.edu (E.L.)

* Author to whom correspondence should be addressed; E-Mail: tang@bio.fsu.edu; Tel.: +1-850-645-2402; Fax: +1-850-645-8447.

Received: 22 May 2013; in revised form: 26 June 2013 / Accepted: 3 July 2013 /

Published: 11 July 2013

\begin{abstract}
Cyclophilins are peptidyl-prolyl cis/trans isomerases important in the proper folding of certain proteins. Mounting evidence supports varied roles of cyclophilins, either positive or negative, in the life cycles of diverse viruses, but the nature and mechanisms of these roles are yet to be defined. The potential for cyclophilins to serve as a drug target for antiviral therapy is evidenced by the success of non-immunosuppressive cyclophilin inhibitors (CPIs), including Alisporivir, in clinical trials targeting hepatitis $\mathrm{C}$ virus infection. In addition, as cyclophilins are implicated in the predisposition to, or severity of, various diseases, the ability to specifically and effectively modulate their function will prove increasingly useful for disease intervention. In this review, we will summarize the evidence of cyclophilins as key mediators of viral infection and prospective drug targets.
\end{abstract}

Keywords: cyclosporin; HIV; HCV; cyclophilin

\section{Introduction}

Unlike other infective agents, viruses do not encode a full complement of proteins that allow them to proliferate independent of the host. Consequently, the life cycles of all viruses depend upon numerous host proteins which may be generally termed host cofactors. Increased understanding of how viruses co-opt host cofactors to generate and maintain a permissive environment for their replication has highlighted targets for antiviral intervention. A substantial body of evidence supports a role in diverse viral life cycles for the cyclophilins, a family of highly conserved peptidyl-prolyl cis/trans isomerases. 


\section{Peptidyl-Prolyl cis/trans Isomerases (PPIases) and Cyclophilins}

Peptide bonds joining adjacent amino acids have partial double bond character, which restricts the free rotations of these bonds. For most peptide bonds, two energetically-preferred states exist, of which the trans state is favored due to steric hindrance in the cis state. Crossing between these states is energetically costly. In Xaa-Pro peptide bonds, however, the energy minima are more similar between the cis and trans isomers, resulting in a higher percentage of isomers containing cis peptidyl-prolyl bonds. The stereostate of the peptidyl-prolyl bond is critical in many biological processes including signaling, enzyme function, and membrane trafficking. Spontaneous interconversion, however, occurs at a physiologically-impractical rate (i.e., order of seconds), potentially 'trapping' proline-containing regions of a protein in a particular conformation. In 1984, a novel enzyme, peptidyl-prolyl cis/trans isomerase (PPIase), was isolated that catalyzed this cis/trans interconversion, through the use of a target peptide sequence Ala-Ala-Pro-Phe and a chymotrypsin-coupled protease assay. In this peptide, a majority of the peptidyl-prolyl bonds are in the trans state, making it a high affinity substrate for the protease. The minority cis isomers are poor substrates and are cleaved at a rate determined by the spontaneous isomerization of proline, a rate which is greatly enhanced by the PPIase [1]. In addition, the enzyme was shown to be involved in the refolding of urea-denatured ribonuclease $\mathrm{A}$, a cellular protein [2]. Independent concurrent efforts to identify the cellular receptor for the immunosuppressant cyclosporine A (CsA) led to the discovery of a cytosolic protein with high affinity for CsA [3]. This protein, termed cyclophilin ( $\mathrm{CyP})$, would turn out to be the same protein as PPIase [4,5]. In humans, this protein is the $18 \mathrm{kDa}$ cyclophilin A (hCyPA), encoded by the gene PPIA. Human CyPA mediates the immunosuppressive function of CsA through the formation of a CsA/CyPA complex. This complex binds to and inhibits the function of the protein phosphatase calcineurin [6], which normally functions to dephosphorylate NF-AT, a transcription factor important for T cell activation.

Cyclophilin genes are found in the genomes of all domains of life including that of a mimivirus $[7,8]$. The cyclophilin family is large and has been implicated in various diseases including cancer, diabetes, neurodegeneration, and atherosclerosis (Table 1). They are defined by the presence of a conserved cyclophilin-like domain (CLD) but many also contain additional domains that may function independent of the CLD. Furthermore, some CLDs did not exhibit PPIase activity when tested in vitro [9], suggesting that even the single domain cyclophilins may have PPIase-independent roles such as protein chaperoning and quaternary structure regulation.

Other than cyclophilins, the FK506-binding proteins (FKBPs) also exhibit PPIase activities [10,11]. FK506 is another immunosuppressant that inhibits lymphocyte activation and has been used clinically to facilitate transplant and graft acceptance. Together, cyclophilins and FKBPs comprise the immunophilin family, so named for their binding of the immunosuppressive agents CsA, FK506, and rapamycin. At least thirteen human genes encode proteins containing from one to four FKBP domains. Like cyclophilins, FKBPs exhibit diverse biological functions. The CsA/CyP and the FK506/FKBP complexes exert their immunosuppressive effects through identical mechanisms. Despite the distinct structures between the compounds and between the proteins, the two complexes nevertheless possess a similar composite surface that binds to calcineurin and inhibits $\mathrm{T}$ cell activation [6]. The rapamycin/FKBP complex, on the other hand, targets the mammalian target of rapamycin (mTOR) pathway to inhibit $\mathrm{T}$ cell proliferation $[12,13]$. Finally, a non-immunophilin class of PPIase, the 
parvulin-like proteins, has also been described and includes two human genes encoding at least three distinct proteins [14].

Table 1. Diversity of the cyclophilins.

\begin{tabular}{|c|c|c|c|c|}
\hline Cyclophilin (Gene) & Localization & Size & CsA Binding & Example Cellular Roles \\
\hline $\begin{array}{l}\text { CyPA }(P P I A) \\
\text { NM_021130 }\end{array}$ & $\begin{array}{l}\text { Cytoplasm; Nucleus; } \\
\text { Secreted }\end{array}$ & $18 \mathrm{kDa}$ & $\mathrm{Y}$ & $\begin{array}{l}\text { Inflammation; tumor progression } \\
{[15-17]}\end{array}$ \\
\hline $\begin{array}{l}\text { CyPB }(P P I B) \\
\text { NM_000942 }\end{array}$ & $\begin{array}{l}\text { ER; Secreted; Cell } \\
\text { surface }\end{array}$ & $20 \mathrm{kDa}$ & Y & $\begin{array}{l}\text { Secretory pathway; inflammation } \\
{[18-22]}\end{array}$ \\
\hline $\begin{array}{l}\text { CyPC }(P P I C) \\
\text { NM_000943 }\end{array}$ & $\begin{array}{l}\text { Cytoplasm; ER; } \\
\text { Secreted }\end{array}$ & $33 \mathrm{kDa}$ & $\mathrm{Y}$ & $\begin{array}{l}\text { Circulating tumor cell survival } \\
{[23,24]}\end{array}$ \\
\hline $\begin{array}{l}\text { CyPD [CyP3] }(P P I F) \\
\text { NM_005729 }\end{array}$ & Mitochondrion & $22 \mathrm{kDa}$ & $\mathrm{Y}$ & $\begin{array}{l}\text { Mitochondrial permeability } \\
\text { transition }(\mathrm{mTP})[25,26]\end{array}$ \\
\hline $\begin{array}{l}\text { CyPE [CyP33](PPIE) } \\
\text { NM_006112 }\end{array}$ & Nucleus & $33 \mathrm{kDa}$ & $\mathrm{Y}$ & mRNA processing [27-30] \\
\hline $\begin{array}{l}\text { Cyp40 (PPID) } \\
\text { NM_005038 }\end{array}$ & Cytoplasm & $41 \mathrm{kDa}$ & Y & Hsp90 chaperone complex $[31,32]$ \\
\hline $\begin{array}{l}\text { CyPNK }(N K T R) \\
\text { NM_005385 }\end{array}$ & Membrane & $150 \mathrm{kDa}$ & $\mathrm{Y}$ & $\begin{array}{l}\text { Tumor recognition in NK cells } \\
{[33,34]}\end{array}$ \\
\hline $\begin{array}{l}\text { CyPG [SR-cyclophilin] } \\
(P P I G) \\
\text { NM_004792 }\end{array}$ & Nucleus & $88 \mathrm{kDa}$ & Y & $\begin{array}{l}\text { Splicing; interaction with RNA } \\
\text { pol II }[35,36]\end{array}$ \\
\hline $\begin{array}{l}\text { CypH [USA- } \\
\text { CyP;SnuCyP-20] } \\
(P P I H) \\
\text { NM_006347 }\end{array}$ & Nucleus; Cytoplasm & $19 \mathrm{kDa}$ & Y & mRNA processing; splicing [37-39] \\
\hline $\begin{array}{l}\text { CyPL1 }(P P I L 1) \\
\text { NM_016059 }\end{array}$ & Nucleus & $18 \mathrm{kDa}$ & Y & mRNA processing [40-42] \\
\hline $\begin{array}{l}\text { CyP60 (PPIL2) } \\
\text { NM_014337 }\end{array}$ & Nucleus; Golgi & $59 \mathrm{kDa}$ & $\mathrm{N}$ & $\begin{array}{l}\text { Cell surface expression of CD147 } \\
{[43,44]}\end{array}$ \\
\hline $\begin{array}{l}\text { CyPJ (PPIL3) } \\
\text { NM_032472 }\end{array}$ & Nucleus & $18 \mathrm{kDa}$ & N.D. & mRNA processing $[45,46]$ \\
\hline $\begin{array}{l}\text { PPIL4 (PPIL4) } \\
\text { NM_139126 }\end{array}$ & Nucleus & $57 \mathrm{kDa}$ & N.D. & [47] \\
\hline $\begin{array}{l}\text { PPIL6 (PPIL6) } \\
\text { NM_173672 }\end{array}$ & & $35 \mathrm{kDa}$ & $\mathrm{N}$ & [9] \\
\hline $\begin{array}{l}\text { RanBP2 [Nup358] } \\
(R A N B P 2) \\
\text { NM_006267 } \\
\end{array}$ & Nucleus & $358 \mathrm{kDa}$ & $\mathrm{N}$ & Nuclear pore complex $[48,49]$ \\
\hline $\begin{array}{l}\text { PPWD1 (PPWD1) } \\
\text { NM_015342 }\end{array}$ & Nucleus & $73 \mathrm{kDa}$ & $\mathrm{Y}$ & mRNA processing $[27,50]$ \\
\hline $\begin{array}{l}\text { SDCCAG-10 (CWC27) } \\
\text { NM_005869 }\end{array}$ & Nucleus & $54 \mathrm{kDa}$ & $\mathrm{N}$ & [51] \\
\hline
\end{tabular}




\section{Cyclophilins and HIV}

The first link between viral replication and a host cyclophilin was reported two decades ago by Luban and colleagues, who identified CyPA and CyPB as interaction partners of the HIV-1 Gag polyprotein using a yeast two-hybrid screen [52]. Subsequently it was reported that CyPA, but not $\mathrm{CyPB}$, is specifically incorporated into HIV-1 virions [53,54] via a specific interaction between residues G89 and P90 of the HIV-1 capsid (CA) and the active site of CyPA [55,56]. Mutations in the CyPA-binding site of CA [57] or knockout of CyPA in a T-cell line [58] significantly impaired HIV-1 replication. Although it was initially hypothesized that virion-associated CyPA was required during the HIV-1 life cycle, later studies revealed a role specifically for CyPA present in the target, rather than the producer cells [59-61]. HIV virions produced in the presence of CsA or from CyPA-knockdown cells did not exhibit any defect in infecting permissive cells, and wildtype virus produced in the presence of CyPA could not productively infect CyPA-depleted target cells. The mechanism by which CyPA functions to facilitate HIV infection is not fully understood but may be related to the regulation of stability of the incoming viral capsid [61-63].

In addition to being a proviral factor in HIV-permissive human cells, the ability of CyPA to bind HIV capsid also contributes to an intrinsic immunity mechanism that underlies species-specific restriction of HIV infection. Early attempts to establish HIV infection in non-human primate cell lines revealed a dominant, capsid-dependent block post-entry and immediately prior to reverse transcription in Old World monkeys [64-69]. The protein responsible for this restriction has been identified in rhesus macaques to be TRIM5 $\alpha$ [70], which binds the incoming viral capsids and halts infection. The human TRIM5 $\alpha$ protein only has weak inhibitory action against HIV-1, likely due to sequence divergences in the C-terminal domain of TRIM5 $\alpha$ that mediate its recognition of the capsid [70]. An involvement of $\mathrm{CyPA}$ in this restriction phenotype was first implicated by the result that CsA treatment of owl monkey cells paradoxically increased HIV infection, presumably counteracting a restriction factor [59]. The discovery of the TRIMCyp fusion gene from owl monkeys [71,72] offered an immediate explanation for this observation: the retrotransposed CyPA domain would target TRIM5 $\alpha$ directly to incoming HIV-1 capsids to exert its antiviral activity; and, disruption of CyPA-CA interaction by $\mathrm{CsA}$ relieves the restriction. In a remarkable example of convergent evolution, perhaps in defense against pathogens, independent retrotranspositions of CyPA into TRIM5 $\alpha$ occurred in several different primate species, resulting in at least three distinct TRIMCyp fusions for which the chimeric protein or transcript is expressed [73-76]. In addition, for some TRIM5 $\alpha$ variants, the restriction function of the unfused TRIM5 $\alpha$ is also dependent on CyPA [77-79]. In this case, CyPA may modulate CA structure to present a better binding surface for TRIM5 $\alpha$ recognition. Regardless of the mechanism, the opposing roles of CyPA in permissive and non-permissive cells, the convergent evolution of TRIMCyp fusion genes, and the multiple ways of using CyPA to gain optimal access to viral capsid all strongly argue for a highly conserved function of CyPA-mediated recognition of viral capsids during the co-evolution of retroviruses and the host cell. Finally, a role of CyPA in HIV pathogenesis is also supported by genome-wide association studies that showed single nucleotide polymorphisms (SNPs) in the regulatory region of the CyPA gene which influence HIV susceptibility [80] or disease progression $[81,82]$, likely through the modulation of CyPA expression. 
Two other HIV proteins, Vpr and p6, have also been reported to interact with CyPA [83,84]. The CyPA-binding site on Vpr was first mapped to a proline-containing peptide at the N-terminus [83], but when full-length $\mathrm{Vpr}$ was assayed for interaction, a proline-free region nearer the C-terminus was identified as the site with higher affinity for CyPA, the first such proposed natural binding sequence for CyPA [85,86]. The relevance of CyPA-binding for Vpr function in HIV life cycle (i.e., inducing cell cycle arrest) is controversial $[83,87]$, and it remains to be determined if the p6-CyPA interaction observed in vitro also occurs in the infected cells [84].

Another cyclophilin that has been implicated in the HIV-1 lifecycle is RanBP2. Also named Nup358, RanBP2 is a large protein containing a C-terminal CLD. It is a component of the nuclear pore complex (NPC), of which HIV relies on to transport replication intermediates. RanBP2 was identified in two genomic siRNA screens as a host factor required for HIV infection, specifically the nuclear import of preintegration complexes (PICs) [88,89]. More recently, HIV-1 CA was shown to directly bind the CLD of RanBP2 and this interaction may influence PIC import as well as the integration preference of the viral genome [90,91]. Unlike the CyPA-CA interaction, the RanBP2-CA interaction is insensitive to CsA. Surprisingly, CyPA depletion in RanBP2 knockdown cells rescued HIV infectivity, supporting a role of these two CA-binding cyclophilins in the same nuclear import pathway [90]. These results are consistent with previous studies which implicated CyPA in nuclear transport [92-94]. Indeed, as suggested by Schaller et al. [90], CLD-containing proteins may act to regulate timing of critical events. In this case, the authors propose monomeric CyPA may act to stabilize the HIV-1 CA until it reaches the nuclear pore whereas the multiple copies of RanBP2 present in the NPC promote uncoating.

\section{Cyclophilins and HCV}

Following the reports of a direct anti-HCV effect of CsA in the HCV replicon systems [95,96], an essential role of cyclophilins in HCV replication was further supported by the correlation between the ability of the different CsA derivatives to bind cyclophilins and to inhibit HCV [97]. The identity of the specific isoform of cyclophilin most important for HCV replication, however, was initially controversial [97-99] until several independent groups demonstrated that CyPA is universally and specifically required for HCV infection [100-104]. This was perhaps not surprising when considering the high expression of the CyPA isoform relative to other members of the CyP family. It was also demonstrated that the PPIase motif of CyPA is required for it to function as a HCV cofactor [101-103]. Intriguingly, SNPs in the PPIA gene that destabilize CyPA can protect hepatocytes from HCV infection in cell culture [105], suggesting PPIA SNPs contribute to the observed heterogeneity of HCV permissiveness in hepatoma cell populations in vitro.

The precise roles of CyPA in the HCV life cycle, and therefore the antiviral mechanisms of CsA and its derivatives, are still not fully understood. CyPA has been proposed to stabilize the HCV replication complex through binding of the HCV replicase [103]; to modulate the RNA-binding properties of the nonstructural protein 5A (NS5A) [106,107]; to act as a cofactor for the RNA-dependent RNA polymerase [97]; and to influence processing of HCV polyproteins [101]. CyPA may also play a role in more than one step of the HCV infection cycle. Early CsA inhibition studies $[95,96,100]$ used subgenomic replicon assays which only measure RNA replication but not other steps 
such as entry or assembly. The subsequent observation of differences in the cyclophilin inhibitor (CPI) sensitivity between subgenomic replicons and full-length viruses suggested a function of cyclophilins in an additional step such as viral assembly [104]. Determining a specific role of CyPA in HCV assembly had been difficult, however, due to the fact that replication is a prerequisite for assembly in the natural infection cycle. To overcome this obstacle, Nag et al. devised an approach to normalize RNA replication first, and then, specifically examine assembly in CyPA knockdown cells [107]. These results demonstrated that $\mathrm{CyPA}$ indeed plays an additional role at the assembly step of HCV life cycle. A recent report showed that $\mathrm{CyPA}$ could also interact with the interferon (IFN) regulatory factor 9 (IRF9) [108] in vitro. However, because previous studies have demonstrated that CsA functions through an IFN-independent mechanism [95,99], the significance of the CyPA-IRF9 interaction remains unclear.

An involvement of NS5A in CyPA's action was first implicated by an analysis of mutations that conferred CsA resistance to HCV replicon in vitro [109] and later confirmed by the demonstration of a direct interaction between recombinant NS5A domain II and CyPA [110]. Even though other viral proteins, including NS5B and NS2, have also been suggested to be targets of CyPA, the NS5A-CyPA interaction has the strongest experimental support [110-113], and, in contrast to the well-defined HIV-1 CA CyPA-binding site, multiple proline residues serve as the putative substrates for CyPA's PPIase activity in domains II and III of NS5A [110,111,114,115]. Elucidating the structural changes of NS5A induced by CyPA-binding and isomerization is the next logical step but will be challenging because of the intrinsically disordered nature of these domains [116,117].

Despite the strong inhibitory effect of CsA in vitro, the in vivo effect of CsA on HCV infection and disease progression is less clear, at least in liver transplant patients. Direct comparison of patients who received either CsA or Tacrolimus (FK506), the latter of which did not have any anti-HCV effect in vitro, failed to show significant difference in the severity of recurrent HCV in most studies [118-121]. On the other hand, combination of IFN- $\alpha$ and CsA was more effective in achieving sustained virologic response than IFN- $\alpha$ monotherapy, especially in patients with genotype 1 virus, high viral load, or both $[122,123]$. More interestingly, clinical trials of CsA derivatives lacking immunosuppressive function have shown that these compounds can potently suppress HCV viral load in patients and may become part of the future combination therapy against HCV [124,125]. Several reasons could account for the differences between the transplant patient results and the positive clinical studies. First, the immune functions of the transplant patients are suppressed by CsA and the antiviral effect alone may not be enough to suppress the virus; all the anti-HCV clinical CPIs lack the immunosuppressive function. Second, the standard dosage of CsA used in the transplant patients was too low as far as the anti-HCV function is concerned. The leading CPI, (Alisporivir), which was already more potent than CsA at inhibiting $\mathrm{HCV}$ replication in vitro, was given at least twice the daily dosage, and more frequently, than that of CsA in liver transplant patients. Finally, sequence polymorphisms flanking conserved regions of NS5A may affect in vivo susceptibility to CsA [150]. Development of non-CsAderived CPIs may offer structural diversity in this class of host-targeting compounds [126].

In vitro $\mathrm{HCV}$ resistance to CPIs has been reported variously and recent data point to a conserved, proline-rich region in NS5A domain II as the hotspot for developing resistance mutations $[111,113,127,128]$. These mutations do not affect the affinity of NS5A for CyPA and may instead function by promoting a conformational tendency naturally induced by CyPA binding [111]. Unlike 
viral resistance to direct antiviral agents (DAAs), the magnitude of the in vitro resistance to CPIs is relatively low (less than 20 fold as opposed to thousands of folds). Consistent with this, the genetic barriers that CPIs poses in clinical studies are also higher than DAAs [129]. A common concern for targeting a host protein is the associated cellular toxicity; however, in the case of CyPA, knockout studies both in a human cell line and mice suggest CyPA is dispensable for basic cell survival $[58,130]$.

\section{Cyclophilins and Other Viruses}

The potential role of cyclophilins in the replication of influenza virus has been detailed in a separate review in this special issue [131]. In yeast, the CyPA homolog Cpr1p inhibits viral replication proteins of tombusvirus [132]. Interestingly, a parvulin PPIase could also inhibit tombusvirus in this model, supporting overlapping functionality among PPIase classes. West Nile virus RNA and its nonstructural protein 5 (NS5) were found to interact directly with CyPA in infected cells in a CsA-sensitive manner [133], although the CsA was much less active in inhibiting WNV than HCV. The replication and pathogenesis of many other human viruses have been reported to be regulated either by CsA or cyclophilins. These include polyomavirus BK [134], arterivirus [135], rotavirus [136], human cytomegalovirus [137], vesicular stomatitis virus [138], vaccinia virus [139,140], measles virus [141], human papillomavirus [142,143], coronaviruses [144-146], and hepatitis B virus [147-149].

\section{Concluding Remarks}

While the diversity of potential functions of host cyclophilins in viral life cycles is evident, what is less apparent is the conservation of these roles. For example, whether most cyclophilin-virus interactions are unique to particular viruses or part of larger, broad themes is uncertain. Furthermore, the cellular and viral substrates of cyclophilins are not fully defined, nor are the implications of catalytically altering the conformation of folded protein. CLD-containing proteins are found in all domains of life and are even found within the genome of at least one virus, the mimivirus [7,8], highlighting the conserved and critical role cyclophilins likely play in the host cell. Further research effort towards understanding the role cyclophilins play in both viral life cycles and normal cell physiology will expand our understanding of the cell as a whole and reveal new host drug targets.

\section{Acknowledgments}

Work in authors' lab is supported by NIH grant R01 AI079150 to H.T.

\section{Conflict of Interest}

The authors declare no conflict of interest.

\section{References and Notes}

1. Fischer, G.; Bang, H.; Mech, C. Determination of enzymatic catalysis for the cis-transisomerization of peptide binding in proline-containing peptides. Biomed. Biochim. Acta 1984, 43, $1101-1111$. 
2. Fischer, G.; Bang, H. The refolding of urea-denatured ribonuclease A is catalyzed by peptidyl-prolyl cis-trans isomerase. Biochim. Biophys. Acta 1985, 828, 39-42.

3. Handschumacher, R.E.; Harding, M.W.; Rice, J.; Drugge, R.J.; Speicher, D.W. Cyclophilin: A specific cytosolic binding protein for cyclosporin A. Science 1984, 226, 544-547.

4. Fischer, G.; Wittmann-Liebold, B.; Lang, K.; Kiefhaber, T.; Schmid, F.X. Cyclophilin and peptidyl-prolyl cis-trans isomerase are probably identical proteins. Nature 1989, 337, 476-478.

5. Takahashi, N.; Hayano, T.; Suzuki, M. Peptidyl-prolyl cis-trans isomerase is the cyclosporin A-binding protein cyclophilin. Nature 1989, 337, 473-475.

6. Liu, J.; Farmer, J.D., Jr.; Lane, W.S.; Friedman, J.; Weissman, I.; Schreiber, S.L. Calcineurin is a common target of cyclophilin-cyclosporin A and FKBP-FK506 complexes. Cell 1991, 66, 807-815.

7. Thai, V.; Renesto, P.; Fowler, C.A.; Brown, D.J.; Davis, T.; Gu, W.; Pollock, D.D.; Kern, D.; Raoult, D.; Eisenmesser, E.Z. Structural, biochemical, and in vivo characterization of the first virally encoded cyclophilin from the Mimivirus. J. Mol. Biol. 2008, 378, 71-86.

8. Raoult, D.; Audic, S.; Robert, C.; Abergel, C.; Renesto, P.; Ogata, H.; La Scola, B.; Suzan, M.; Claverie, J.M. The 1.2-megabase genome sequence of Mimivirus. Science 2004, 306, 1344-1350.

9. Davis, T.L.; Walker, J.R.; Campagna-Slater, V.; Finerty, P.J.; Paramanathan, R.; Bernstein, G.; MacKenzie, F.; Tempel, W.; Ouyang, H.; Lee, W.H.; et al. Structural and biochemical characterization of the human cyclophilin family of peptidyl-prolyl isomerases. PLoS Biol. 2010, 8, e1000439.

10. Siekierka, J.J.; Hung, S.H.; Poe, M.; Lin, C.S.; Sigal, N.H. A cytosolic binding protein for the immunosuppressant FK506 has peptidyl-prolyl isomerase activity but is distinct from cyclophilin. Nature 1989, 341, 755-757.

11. Harding, M.W.; Galat, A.; Uehling, D.E.; Schreiber, S.L. A receptor for the immunosuppressant FK506 is a cis-trans peptidyl-prolyl isomerase. Nature 1989, 341, 758-760.

12. Brown, E.J.; Albers, M.W.; Shin, T.B.; Ichikawa, K.; Keith, C.T.; Lane, W.S.; Schreiber, S.L. A mammalian protein targeted by G1-arresting rapamycin-receptor complex. Nature 1994, 369, 756-758.

13. Sabatini, D.M.; Erdjument-Bromage, H.; Lui, M.; Tempst, P.; Snyder, S.H. RAFT1: A mammalian protein that binds to FKBP12 in a rapamycin-dependent fashion and is homologous to yeast TORs. Cell 1994, 78, 35-43.

14. Rahfeld, J.U.; Rucknagel, K.P.; Schelbert, B.; Ludwig, B.; Hacker, J.; Mann, K.; Fischer, G. Confirmation of the existence of a third family among peptidyl-prolyl cis/trans isomerases. Amino acid sequence and recombinant production of parvulin. FEBS Lett. 1994, 352, 180-184.

15. Sherry, B.; Yarlett, N.; Strupp, A.; Cerami, A. Identification of cyclophilin as a proinflammatory secretory product of lipopolysaccharide-activated macrophages. Proc. Natl. Acad. Sci. USA 1992, 89, 3511-3515.

16. Arora, K.; Gwinn, W.M.; Bower, M.A.; Watson, A.; Okwumabua, I.; MacDonald, H.R.; Bukrinsky, M.I.; Constant, S.L. Extracellular cyclophilins contribute to the regulation of inflammatory responses. J. Immunol. 2005, 175, 517-522.

17. Lee, J.; Kim, S.S. Current implications of cyclophilins in human cancers. J. Exp. Clin. Cancer Res. 2010, 29, 97. 
18. Pakula, R.; Melchior, A.; Denys, A.; Vanpouille, C.; Mazurier, J.; Allain, F. Syndecan-1/CD147 association is essential for cyclophilin B-induced activation of p44/42 mitogen-activated protein kinases and promotion of cell adhesion and chemotaxis. Glycobiology 2007, 17, 492-503.

19. Marcant, A.; Denys, A.; Melchior, A.; Martinez, P.; Deligny, A.; Carpentier, M.; Allain, F. Cyclophilin B attenuates the expression of TNF-alpha in lipopolysaccharide-stimulated macrophages through the induction of B cell lymphoma-3. J. Immunol. 2012, 189, 2023-2032.

20. Price, E.R.; Zydowsky, L.D.; Jin, M.J.; Baker, C.H.; McKeon, F.D.; Walsh, C.T. Human cyclophilin B: A second cyclophilin gene encodes a peptidyl-prolyl isomerase with a signal sequence. Proc. Natl. Acad. Sci. USA 1991, 88, 1903-1907.

21. Hasel, K.W.; Glass, J.R.; Godbout, M.; Sutcliffe, J.G. An endoplasmic reticulum-specific cyclophilin. Mol. Cell. Biol. 1991, 11, 3484-3491.

22. Allain, F.; Vanpouille, C.; Carpentier, M.; Slomianny, M.C.; Durieux, S.; Spik, G. Interaction with glycosaminoglycans is required for cyclophilin B to trigger integrin-mediated adhesion of peripheral blood T lymphocytes to extracellular matrix. Proc. Natl. Acad. Sci. USA 2002, 99, 2714-2719.

23. Friedman, J.; Weissman, I. Two cytoplasmic candidates for immunophilin action are revealed by affinity for a new cyclophilin: One in the presence and one in the absence of CsA. Cell 1991, 66, 799-806.

24. Obermayr, E.; Castillo-Tong, D.C.; Pils, D.; Speiser, P.; Braicu, I.; Van Gorp, T.; Mahner, S.; Sehouli, J.; Vergote, I.; Zeillinger, R. Molecular characterization of circulating tumor cells in patients with ovarian cancer improves their prognostic significance-A study of the OVCAD consortium. Gynecol. Oncol. 2013, 128, 15-21.

25. Baines, C.P.; Kaiser, R.A.; Purcell, N.H.; Blair, N.S.; Osinska, H.; Hambleton, M.A.; Brunskill, E.W.; Sayen, M.R.; Gottlieb, R.A.; Dorn, G.W.; et al. Loss of cyclophilin D reveals a critical role for mitochondrial permeability transition in cell death. Nature 2005, 434, 658-662.

26. Schinzel, A.C.; Takeuchi, O.; Huang, Z.; Fisher, J.K.; Zhou, Z.; Rubens, J.; Hetz, C.; Danial, N.N.; Moskowitz, M.A.; Korsmeyer, S.J. Cyclophilin D is a component of mitochondrial permeability transition and mediates neuronal cell death after focal cerebral ischemia. Proc. Natl. Acad. Sci. USA 2005, 102, 12005-12010.

27. Jurica, M.S.; Licklider, L.J.; Gygi, S.R.; Grigorieff, N.; Moore, M.J. Purification and characterization of native spliceosomes suitable for three-dimensional structural analysis. $R N A$ 2002, 8, 426-439.

28. Kim, J.O.; Nau, M.M.; Allikian, K.A.; Makela, T.P.; Alitalo, K.; Johnson, B.E.; Kelley, M.J. Co-amplification of a novel cyclophilin-like gene (PPIE) with L-myc in small cell lung cancer cell lines. Oncogene 1998, 17, 1019-1026.

29. Mi, H.; Kops, O.; Zimmermann, E.; Jaschke, A.; Tropschug, M. A nuclear RNA-binding cyclophilin in human T cells. FEBS Lett. 1996, 398, 201-205.

30. Wang, Y.; Han, R.; Zhang, W.; Yuan, Y.; Zhang, X.; Long, Y.; Mi, H. Human CyP33 binds specifically to mRNA and binding stimulates PPIase activity of hCyP33. FEBS Lett. 2008, 582, 835-839.

31. Dartigalongue, C.; Raina, S. A new heat-shock gene, ppiD, encodes a peptidyl-prolyl isomerase required for folding of outer membrane proteins in Escherichia coli. EMBO J. 1998, 17, 3968-3980. 
32. Pirkl, F.; Buchner, J. Functional analysis of the Hsp90-associated human peptidyl prolyl cis/trans isomerases FKBP51, FKBP52 and Cyp40. J. Mol. Biol. 2001, 308, 795-806.

33. Rinfret, A.; Collins, C.; Menard, R.; Anderson, S.K. The N-terminal cyclophilin-homologous domain of a 150-kilodalton tumor recognition molecule exhibits both peptidylprolyl cis-transisomerase and chaperone activities. Biochemistry 1994, 33, 1668-1673.

34. Anderson, S.K.; Gallinger, S.; Roder, J.; Frey, J.; Young, H.A.; Ortaldo, J.R. A cyclophilinrelated protein involved in the function of natural killer cells. Proc. Natl. Acad. Sci. USA 1993, 90, 542-546.

35. Nestel, F.P.; Colwill, K.; Harper, S.; Pawson, T.; Anderson, S.K. RS cyclophilins: Identification of an NK-TR1-related cyclophilin. Gene 1996, 180, 151-155.

36. Bourquin, J.P.; Stagljar, I.; Meier, P.; Moosmann, P.; Silke, J.; Baechi, T.; Georgiev, O.; Schaffner, W. A serine/arginine-rich nuclear matrix cyclophilin interacts with the C-terminal domain of RNA polymerase II. Nucleic Acids Res. 1997, 25, 2055-2061.

37. Horowitz, D.S.; Kobayashi, R.; Krainer, A.R. A new cyclophilin and the human homologues of yeast Prp3 and Prp4 form a complex associated with U4/U6 snRNPs. RNA 1997, 3, 1374-1387.

38. Teigelkamp, S.; Achsel, T.; Mundt, C.; Gothel, S.F.; Cronshagen, U.; Lane, W.S.; Marahiel, M.; Luhrmann, R. The $20 \mathrm{kD}$ protein of human [U4/U6.U5] tri-snRNPs is a novel cyclophilin that forms a complex with the U4/U6-specific $60 \mathrm{kD}$ and $90 \mathrm{kD}$ proteins. $R N A 1998,4,127-141$.

39. Horowitz, D.S.; Lee, E.J.; Mabon, S.A.; Misteli, T. A cyclophilin functions in pre-mRNA splicing. EMBO J. 2002, 21, 470-480.

40. Ozaki, K.; Fujiwara, T.; Kawai, A.; Shimizu, F.; Takami, S.; Okuno, S.; Takeda, S.; Shimada, Y.; Nagata, M.; Watanabe, T.; et al. Cloning, expression and chromosomal mapping of a novel cyclophilin-related gene (PPIL1) from human fetal brain. Cytogenet. Cell Genet. 1996, 72, 242-245.

41. Jurica, M.S.; Moore, M.J. Pre-mRNA splicing: Awash in a sea of proteins. Mol. Cell 2003, 12, 5-14.

42. Xu, C.; Zhang, J.; Huang, X.; Sun, J.; Xu, Y.; Tang, Y.; Wu, J.; Shi, Y.; Huang, Q.; Zhang, Q. Solution structure of human peptidyl prolyl isomerase-like protein 1 and insights into its interaction with SKIP. J. Biol. Chem. 2006, 281, 15900-15908.

43. Pushkarsky, T.; Yurchenko, V.; Vanpouille, C.; Brichacek, B.; Vaisman, I.; Hatakeyama, S.; Nakayama, K.I.; Sherry, B.; Bukrinsky, M.I. Cell surface expression of CD147/EMMPRIN is regulated by cyclophilin 60. J. Biol. Chem. 2005, 280, 27866-27871.

44. Wang, B.B.; Hayenga, K.J.; Payan, D.G.; Fisher, J.M. Identification of a nuclear-specific cyclophilin which interacts with the proteinase inhibitor eglin c. Biochem. J. 1996, 314, 313-319.

45. Zhou, Z.; Ying, K.; Dai, J.; Tang, R.; Wang, W.; Huang, Y.; Zhao, W.; Xie, Y.; Mao, Y. Molecular cloning and characterization of a novel peptidylprolyl isomerase (cyclophilin)-like gene (PPIL3) from human fetal brain. Cytogenet. Cell Genet. 2001, 92, 231-236.

46. Mesa, A.; Somarelli, J.A.; Herrera, R.J. Spliceosomal immunophilins. FEBS Lett. 2008, 582, 2345-2351.

47. Zeng, L.; Zhou, Z.; Xu, J.; Zhao, W.; Wang, W.; Huang, Y.; Cheng, C.; Xu, M.; Xie, Y.; Mao, Y. Molecular cloning, structure and expression of a novel nuclear RNA-binding cyclophilin-like gene (PPIL4) from human fetal brain. Cytogenet. Cell Genet. 2001, 95, 43-47. 
48. Beddow, A.L.; Richards, S.A.; Orem, N.R.; Macara, I.G. The Ran/TC4 GTPase-binding domain: Identification by expression cloning and characterization of a conserved sequence motif. Proc. Natl. Acad. Sci. USA 1995, 92, 3328-3332.

49. Wu, J.; Matunis, M.J.; Kraemer, D.; Blobel, G.; Coutavas, E. Nup358, a cytoplasmically exposed nucleoporin with peptide repeats, Ran-GTP binding sites, zinc fingers, a cyclophilin A homologous domain, and a leucine-rich region. J. Biol. Chem. 1995, 270, 14209-14213.

50. Davis, T.L.; Walker, J.R.; Ouyang, H.; MacKenzie, F.; Butler-Cole, C.; Newman, E.M.; Eisenmesser, E.Z.; Dhe-Paganon, S. The crystal structure of human WD40 repeat-containing peptidylprolyl isomerase (PPWD1). FEBS J. 2008, 275, 2283-2295.

51. Sutherland, H.G.; Mumford, G.K.; Newton, K.; Ford, L.V.; Farrall, R.; Dellaire, G.; Caceres, J.F.; Bickmore, W.A. Large-scale identification of mammalian proteins localized to nuclear sub-compartments. Hum. Mol. Genet. 2001, 10, 1995-2011.

52. Luban, J.; Bossolt, K.L.; Franke, E.K.; Kalpana, G.V.; Goff, S.P. Human immunodeficiency virus type 1 Gag protein binds to cyclophilins A and B. Cell 1993, 73, 1067-1078.

53. Franke, E.K.; Yuan, H.E.; Luban, J. Specific incorporation of cyclophilin A into HIV-1 virions. Nature 1994, 372, 359-362.

54. Thali, M.; Bukovsky, A.; Kondo, E.; Rosenwirth, B.; Walsh, C.T.; Sodroski, J.; Gottlinger, H.G. Functional association of cyclophilin A with HIV-1 virions. Nature 1994, 372, 363-365.

55. Gamble, T.R.; Vajdos, F.F.; Yoo, S.; Worthylake, D.K.; Houseweart, M.; Sundquist, W.I.; Hill, C.P. Crystal structure of human cyclophilin A bound to the amino-terminal domain of HIV-1 capsid. Cell 1996, 87, 1285-1294.

56. Braaten, D.; Ansari, H.; Luban, J. The hydrophobic pocket of cyclophilin is the binding site for the human immunodeficiency virus type $1 \mathrm{Gag}$ polyprotein. J. Virol. 1997, 71, 2107-2113.

57. Braaten, D.; Aberham, C.; Franke, E.K.; Yin, L.; Phares, W.; Luban, J. Cyclosporine A-resistant human immunodeficiency virus type 1 mutants demonstrate that Gag encodes the functional target of cyclophilin A. J. Virol. 1996, 70, 5170-5176.

58. Braaten, D.; Luban, J. Cyclophilin A regulates HIV-1 infectivity, as demonstrated by gene targeting in human T cells. EMBO J. 2001, 20, 1300-1309.

59. Towers, G.J.; Hatziioannou, T.; Cowan, S.; Goff, S.P.; Luban, J.; Bieniasz, P.D. Cyclophilin A modulates the sensitivity of HIV-1 to host restriction factors. Nat. Med. 2003, 9, 1138-1143.

60. Sokolskaja, E.; Sayah, D.M.; Luban, J. Target cell cyclophilin A modulates human immunodeficiency virus type 1 infectivity. J. Virol. 2004, 78, 12800-12808.

61. Hatziioannou, T.; Perez-Caballero, D.; Cowan, S.; Bieniasz, P.D. Cyclophilin interactions with incoming human immunodeficiency virus type 1 capsids with opposing effects on infectivity in human cells. J. Virol. 2005, 79, 176-183.

62. Li, Y.; Kar, A.K.; Sodroski, J. Target cell type-dependent modulation of human immunodeficiency virus type 1 capsid disassembly by cyclophilin A. J. Virol. 2009, 83, 10951-10962.

63. Shah, V.B.; Shi, J.; Hout, D.R.; Oztop, I.; Krishnan, L.; Ahn, J.; Shotwell, M.S.; Engelman, A.; Aiken, C. The host proteins transportin SR2/TNPO3 and cyclophilin A exert opposing effects on HIV-1 uncoating. J. Virol. 2013, 87, 422-432.

64. Shibata, R.; Sakai, H.; Kawamura, M.; Tokunaga, K.; Adachi, A. Early replication block of human immunodeficiency virus type 1 in monkey cells. J. Gen. Virol. 1995, 76, 2723-2730. 
65. Himathongkham, S.; Luciw, P.A. Restriction of HIV-1 (subtype B) replication at the entry step in rhesus macaque cells. Virology 1996, 219, 485-488.

66. Munk, C.; Brandt, S.M.; Lucero, G.; Landau, N.R. A dominant block to HIV-1 replication at reverse transcription in simian cells. Proc. Natl. Acad. Sci. USA 2002, 99, 13843-13848.

67. Besnier, C.; Takeuchi, Y.; Towers, G. Restriction of lentivirus in monkeys. Proc. Natl. Acad. Sci. USA 2002, 99, 11920-11925.

68. Kootstra, N.A.; Munk, C.; Tonnu, N.; Landau, N.R.; Verma, I.M. Abrogation of postentry restriction of HIV-1-based lentiviral vector transduction in simian cells. Proc. Natl. Acad. Sci. USA 2003, 100, 1298-1303.

69. Hofmann, W.; Schubert, D.; LaBonte, J.; Munson, L.; Gibson, S.; Scammell, J.; Ferrigno, P.; Sodroski, J. Species-specific, postentry barriers to primate immunodeficiency virus infection. J. Virol. 1999, 73, 10020-10028.

70. Stremlau, M.; Owens, C.M.; Perron, M.J.; Kiessling, M.; Autissier, P.; Sodroski, J. The cytoplasmic body component TRIM5alpha restricts HIV-1 infection in Old World monkeys. Nature 2004, 427, 848-853.

71. Sayah, D.M.; Sokolskaja, E.; Berthoux, L.; Luban, J. Cyclophilin A retrotransposition into TRIM5 explains owl monkey resistance to HIV-1. Nature 2004, 430, 569-573.

72. Nisole, S.; Lynch, C.; Stoye, J.P.; Yap, M.W. A Trim5-cyclophilin A fusion protein found in owl monkey kidney cells can restrict HIV-1. Proc. Natl. Acad. Sci. USA 2004, 101, 13324-13328.

73. Wilson, S.J.; Webb, B.L.; Ylinen, L.M.; Verschoor, E.; Heeney, J.L.; Towers, G.J. Independent evolution of an antiviral TRIMCyp in rhesus macaques. Proc. Natl. Acad. Sci. USA 2008, 105, 3557-3562.

74. Brennan, G.; Kozyrev, Y.; Hu, S.L. TRIMCyp expression in Old World primates Macaca nemestrina and Macaca fascicularis. Proc. Natl. Acad. Sci. USA 2008, 105, 3569-3574.

75. Newman, R.M.; Hall, L.; Kirmaier, A.; Pozzi, L.A.; Pery, E.; Farzan, M.; O'Neil, S.P.; Johnson, W. Evolution of a TRIM5-CypA splice isoform in old world monkeys. PLoS Pathog. 2008, 4, e1000003.

76. Virgen, C.A.; Kratovac, Z.; Bieniasz, P.D.; Hatziioannou, T. Independent genesis of chimeric TRIM5-cyclophilin proteins in two primate species. Proc. Natl. Acad. Sci. USA 2008, 105, 3563-3568.

77. Berthoux, L.; Sebastian, S.; Sokolskaja, E.; Luban, J. Cyclophilin A is required for TRIM5 \{alpha\}-mediated resistance to HIV-1 in Old World monkey cells. Proc. Natl. Acad. Sci. USA 2005, 102, 14849-14853.

78. Stremlau, M.; Song, B.; Javanbakht, H.; Perron, M.; Sodroski, J. Cyclophilin A: An auxiliary but not necessary cofactor for TRIM5alpha restriction of HIV-1. Virology 2006, 351, 112-120.

79. Keckesova, Z.; Ylinen, L.M.; Towers, G.J. Cyclophilin A renders human immunodeficiency virus type 1 sensitive to Old World monkey but not human TRIM5 alpha antiviral activity. J. Virol. 2006, 80, 4683-4690.

80. Rits, M.A.; van Dort, K.A.; Kootstra, N.A. Polymorphisms in the regulatory region of the Cyclophilin A gene influence the susceptibility for HIV-1 infection. PLoS One 2008, 3, e3975. 
81. Bleiber, G.; May, M.; Martinez, R.; Meylan, P.; Ott, J.; Beckmann, J.S.; Telenti, A. Use of a combined ex vivo/in vivo population approach for screening of human genes involved in the human immunodeficiency virus type 1 life cycle for variants influencing disease progression. J. Virol. 2005, 79, 12674-12680.

82. An, P.; Wang, L.H.; Hutcheson-Dilks, H.; Nelson, G.; Donfield, S.; Goedert, J.J.; Rinaldo, C.R.; Buchbinder, S.; Kirk, G.D.; O'Brien, S.J.; et al. Regulatory polymorphisms in the cyclophilin A gene, PPIA, accelerate progression to AIDS. PLoS Pathog. 2007, 3, e88.

83. Zander, K.; Sherman, M.P.; Tessmer, U.; Bruns, K.; Wray, V.; Prechtel, A.T.; Schubert, E.; Henklein, P.; Luban, J.; Neidleman, J.; et al. Cyclophilin A interacts with HIV-1 Vpr and is required for its functional expression. J. Biol. Chem. 2003, 278, 43202-43213.

84. Solbak, S.M.; Reksten, T.R.; Roder, R.; Wray, V.; Horvli, O.; Raae, A.J.; Henklein, P.; Fossen, T. HIV-1 p6-Another viral interaction partner to the host cellular protein cyclophilin A. Biochim. Biophys. Acta 2012, 1824, 667-678.

85. Solbak, S.M.; Wray, V.; Horvli, O.; Raae, A.J.; Flydal, M.I.; Henklein, P.; Nimtz, M.; Schubert, U.; Fossen, T. The host-pathogen interaction of human cyclophilin A and HIV-1 Vpr requires specific N-terminal and novel C-terminal domains. BMC Struct. Biol. 2011, 11, 49.

86. Demange, L.; Moutiez, M.; Vaudry, K.; Dugave, C. Interaction of human cyclophilin hCyp-18 with short peptides suggests the existence of two functionally independent subsites. FEBS Lett. 2001, 505, 191-195.

87. Ardon, O.; Zimmerman, E.S.; Andersen, J.L.; DeHart, J.L.; Blackett, J.; Planelles, V. Induction of G2 arrest and binding to cyclophilin A are independent phenotypes of human immunodeficiency virus type 1 Vpr. J. Virol. 2006, 80, 3694-3700.

88. Brass, A.L.; Dykxhoorn, D.M.; Benita, Y.; Yan, N.; Engelman, A.; Xavier, R.J.; Lieberman, J.; Elledge, S.J. Identification of host proteins required for HIV infection through a functional genomic screen. Science 2008, 319, 921-926.

89. Konig, R.; Zhou, Y.; Elleder, D.; Diamond, T.L.; Bonamy, G.M.; Irelan, J.T.; Chiang, C.Y.; Tu, B.P.; de Jesus, P.D.; Lilley, C.E.; et al. Global analysis of host-pathogen interactions that regulate early-stage HIV-1 replication. Cell 2008, 135, 49-60.

90. Schaller, T.; Ocwieja, K.E.; Rasaiyaah, J.; Price, A.J.; Brady, T.L.; Roth, S.L.; Hue, S.; Fletcher, A.J.; Lee, K.; KewalRamani, V.N.; et al. HIV-1 capsid-cyclophilin interactions determine nuclear import pathway, integration targeting and replication efficiency. PLoS Pathog. 2011, 7, e1002439.

91. Ocwieja, K.E.; Brady, T.L.; Ronen, K.; Huegel, A.; Roth, S.L.; Schaller, T.; James, L.C.; Towers, G.J.; Young, J.A.; Chanda, S.K.; et al. HIV integration targeting: A pathway involving Transportin-3 and the nuclear pore protein RanBP2. PLoS Pathog. 2011, 7, e1001313.

92. Ansari, H.; Greco, G.; Luban, J. Cyclophilin A peptidyl-prolyl isomerase activity promotes ZPR1 nuclear export. Mol. Cell. Biol. 2002, 22, 6993-7003.

93. Zhu, C.; Wang, X.; Deinum, J.; Huang, Z.; Gao, J.; Modjtahedi, N.; Neagu, M.R.; Nilsson, M.; Eriksson, P.S.; Hagberg, H.; et al. Cyclophilin A participates in the nuclear translocation of apoptosis-inducing factor in neurons after cerebral hypoxia-ischemia. J. Exp. Med. 2007, 204, $1741-1748$. 
94. Pan, H.; Luo, C.; Li, R.; Qiao, A.; Zhang, L.; Mines, M.; Nyanda, A.M.; Zhang, J.; Fan, G.H. Cyclophilin $\mathrm{A}$ is required for CXCR4-mediated nuclear export of heterogeneous nuclear ribonucleoprotein A2, activation and nuclear translocation of ERK1/2, and chemotactic cell migration. J. Biol. Chem. 2008, 283, 623-637.

95. Watashi, K.; Hijikata, M.; Hosaka, M.; Yamaji, M.; Shimotohno, K. Cyclosporin A suppresses replication of hepatitis $\mathrm{C}$ virus genome in cultured hepatocytes. Hepatology 2003, 38, 1282-1288.

96. Nakagawa, M.; Sakamoto, N.; Enomoto, N.; Tanabe, Y.; Kanazawa, N.; Koyama, T.; Kurosaki, M.; Maekawa, S.; Yamashiro, T.; Chen, C.H.; et al. Specific inhibition of hepatitis C virus replication by cyclosporin A. Biochem. Biophys. Res. Commun. 2004, 313, 42-47.

97. Watashi, K.; Ishii, N.; Hijikata, M.; Inoue, D.; Murata, T.; Miyanari, Y.; Shimotohno, K. Cyclophilin B is a functional regulator of hepatitis C virus RNA polymerase. Mol. Cell 2005, 19, 111-122.

98. Nakagawa, M.; Sakamoto, N.; Tanabe, Y.; Koyama, T.; Itsui, Y.; Takeda, Y.; Chen, C.H.; Kakinuma, S.; Oooka, S.; Maekawa, S.; et al. Suppression of hepatitis C virus replication by cyclosporin a is mediated by blockade of cyclophilins. Gastroenterology 2005, 129, 1031-1041.

99. Robida, J.M.; Nelson, H.B.; Liu, Z.; Tang, H. Characterization of hepatitis C virus subgenomic replicon resistance to cyclosporine in vitro. J. Virol. 2007, 81, 5829-5840.

100. Yang, F.; Robotham, J.M.; Nelson, H.B.; Irsigler, A.; Kenworthy, R.; Tang, H. Cyclophilin a is an essential cofactor for hepatitis $\mathrm{C}$ virus infection and the principal mediator of cyclosporine resistance in vitro. J. Virol. 2008, 82, 5269-5278.

101. Kaul, A.; Stauffer, S.; Berger, C.; Pertel, T.; Schmitt, J.; Kallis, S.; Zayas, M.; Lohmann, V.; Luban, J.; Bartenschlager, R. Essential role of cyclophilin A for hepatitis C virus replication and virus production and possible link to polyprotein cleavage kinetics. PLoS Pathog. 2009, 5, e1000546.

102. Chatterji, U.; Bobardt, M.; Selvarajah, S.; Yang, F.; Tang, H.; Sakamoto, N.; Vuagniaux, G.; Parkinson, T.; Gallay, P. The isomerase active site of cyclophilin A is critical for hepatitis C virus replication. J. Biol. Chem. 2009, 284, 16998-17005.

103. Liu, Z.; Yang, F.; Robotham, J.M.; Tang, H. Critical role of cyclophilin A and its prolyl-peptidyl isomerase activity in the structure and function of the hepatitis $\mathrm{C}$ virus replication complex. J. Virol. 2009, 83, 6554-6565.

104. Ciesek, S.; Steinmann, E.; Wedemeyer, H.; Manns, M.P.; Neyts, J.; Tautz, N.; Madan, V.; Bartenschlager, R.; von Hahn, T.; Pietschmann, T. Cyclosporine A inhibits hepatitis C virus nonstructural protein 2 through cyclophilin A. Hepatology 2009, 50, 1638-1645.

105. Von Hahn, T.; Schiene-Fischer, C.; van, N.D.; Pfaender, S.; Karavul, B.; Steinmann, E.; Potthoff, A.; Strassburg, C.; Hamdi, N.; Abdelaziz, A.I.; et al. Hepatocytes that express variants of cyclophilin A are resistant to HCV infection and replication. Gastroenterology 2012, 143, 439-447.

106. Foster, T.L.; Gallay, P.; Stonehouse, N.J.; Harris, M. Cyclophilin A interacts with domain II of hepatitis $\mathrm{C}$ virus NS5A and stimulates RNA binding in an isomerase-dependent manner. J. Virol. 2011, 85, 7460-7464.

107. Nag, A.; Robotham, J.M.; Tang, H. Suppression of viral RNA binding and the assembly of infectious hepatitis C virus particles in vitro by cyclophilin inhibitors. J. Virol. 2012, 86, 12616-12624. 
108. Bobardt, M.; Hopkins, S.; Baugh, J.; Chatterji, U.; Hernandez, F.; Hiscott, J.; Sluder, A.; Lin, K.; Gallay, P.A. HCV NS5A and IRF9 compete for CypA binding. J. Hepatol. 2013, 58, 16-23.

109. Fernandes, F.; Poole, D.S.; Hoover, S.; Middleton, R.; Andrei, A.C.; Gerstner, J.; Striker, R. Sensitivity of hepatitis $\mathrm{C}$ virus to cyclosporine A depends on nonstructural proteins NS5A and NS5B. Hepatology 2007, 46, 1026-1033.

110. Hanoulle, X.; Badillo, A.; Wieruszeski, J.M.; Verdegem, D.; Landrieu, I.; Bartenschlager, R.; Penin, F.; Lippens, G. Hepatitis C virus NS5A protein is a substrate for the peptidyl-prolyl cis/trans isomerase activity of cyclophilins A and B. J. Biol. Chem. 2009, 284, 13589-13601.

111. Yang, F.; Robotham, J.M.; Grise, H.; Frausto, S.; Madan, V.; Zayas, M.; Bartenschlager, R.; Robinson, M.; Greenstein, A.E.; Nag, A.; et al. A major determinant of cyclophilin dependence and cyclosporine susceptibility of hepatitis $\mathrm{C}$ virus identified by a genetic approach. PLoS Pathog. 2010, 6, e1001118.

112. Chatterji, U.; Lim, P.; Bobardt, M.D.; Wieland, S.; Cordek, D.G.; Vuagniaux, G.; Chisari, F.; Cameron, C.E.; Targett-Adams, P.; Parkinson, T.; et al. HCV resistance to cyclosporin A does not correlate with a resistance of the NS5A-cyclophilin A interaction to cyclophilin inhibitors. J. Hepatol. 2010, 53, 50-56.

113. Fernandes, F.; Ansari, I.U.; Striker, R. cyclosporine inhibits a direct interaction between cyclophilins and hepatitis C NS5A. PLoS One 2010, 5, e9815.

114. Grise, H.; Frausto, S.; Logan, T.; Tang, H. A conserved tandem cyclophilin-binding site in hepatitis $\mathrm{C}$ virus nonstructural protein 5A regulates Alisporivir susceptibility. J. Virol. 2012, 86, 4811-4822.

115. Verdegem, D.; Badillo, A.; Wieruszeski, J.M.; Landrieu, I.; Leroy, A.; Bartenschlager, R.; Penin, F.; Lippens, G.; Hanoulle, X. Domain 3 of NS5A protein from the hepatitis C virus has intrinsic alpha-helical propensity and is a substrate of cyclophilin A. J. Biol. Chem. 2011, 286, 20441-20454.

116. Liang, Y.; Ye, H.; Kang, C.B.; Yoon, H.S. Domain 2 of nonstructural protein 5A (NS5A) of hepatitis $\mathrm{C}$ virus is natively unfolded. Biochemistry 2007, 46, 11550-11558.

117. Hanoulle, X.; Verdegem, D.; Badillo, A.; Wieruszeski, J.M.; Penin, F.; Lippens, G. Domain 3 of non-structural protein 5A from hepatitis $\mathrm{C}$ virus is natively unfolded. Biochem. Biophys. Res. Commun. 2009, 381, 634-638.

118. Hilgard, P.; Kahraman, A.; Lehmann, N.; Seltmann, C.; Beckebaum, S.; Ross, R.S.; Baba, H.A.; Malago, M.; Broelsch, C.E.; Gerken, G. Cyclosporine versus tacrolimus in patients with HCV infection after liver transplantation: Effects on virus replication and recurrent hepatitis. World J. Gastroenterol. 2006, 12, 697-702.

119. Martin, P.; Busuttil, R.W.; Goldstein, R.M.; Crippin, J.S.; Klintmalm, G.B.; Fitzsimmons, W.E.; Uleman, C. Impact of tacrolimus versus cyclosporine in hepatitis $\mathrm{C}$ virus-infected liver transplant recipients on recurrent hepatitis: A prospective, randomized trial. Liver Transpl. 2004, 10, 1258-1262.

120. Guitard, J.; Sandres-Saune, K.; Kamar, N.; Ribes, D.; Faguer, S.; Esposito, L.; Lavit, M.; Muscari, F.; Peron, J.M.; Lavayssiere, L.; et al. Hepatitis C virus viral load after conversion from tacrolimus to cyclosporine in liver transplant patients: A pilot study. Transplant. Proc. 2007, 39, 2603-2605. 
121. Rayhill, S.C.; Barbeito, R.; Katz, D.; Voigt, M.; Labrecque, D.; Kirby, P.; Miller, R.; Stolpen, A.; $\mathrm{Wu}, \mathrm{Y}$.; Schmidt, W. A cyclosporine-based immunosuppressive regimen may be better than tacrolimus for long-term liver allograft survival in recipients transplanted for hepatitis C. Transplant. Proc. 2006, 38, 3625-3628.

122. Inoue, K.; Sekiyama, K.; Yamada, M.; Watanabe, T.; Yasuda, H.; Yoshiba, M. Combined interferon alpha2b and cyclosporin $\mathrm{A}$ in the treatment of chronic hepatitis $\mathrm{C}$ : Controlled trial. J. Gastroenterol. 2003, 38, 567-572.

123. Inoue, K.; Yoshiba, M. Interferon combined with cyclosporine treatment as an effective countermeasure against hepatitis $\mathrm{C}$ virus recurrence in liver transplant patients with end-stage hepatitis C virus related disease. Transplant. Proc. 2005, 37, 1233-1234.

124. Flisiak, R.; Jaroszewicz, J.; Flisiak, I.; Lapinski, T. Update on alisporivir in treatment of viral hepatitis C. Expert Opin. Investig. Drugs 2012, 21, 375-382.

125. Hopkins, S.; Dimassimo, B.; Rusnak, P.; Heuman, D.; Lalezari, J.; Sluder, A.; Scorneaux, B.; Mosier, S.; Kowalczyk, P.; Ribeill, Y.; et al. The cyclophilin inhibitor SCY-635 suppresses viral replication and induces endogenous interferons in patients with chronic HCV genotype 1 infection. J. Hepatol. 2012, 57, 47-54.

126. Gregory, M.A.; Bobardt, M.; Obeid, S.; Chatterji, U.; Coates, N.J.; Foster, T.; Gallay, P.; Leyssen, P.; Moss, S.J.; Neyts, J.; et al. Preclinical characterization of naturally occurring polyketide cyclophilin inhibitors from the sanglifehrin family. Antimicrob. Agents Chemother. 2011, 55, 1975-1981.

127. Goto, K.; Watashi, K.; Inoue, D.; Hijikata, M.; Shimotohno, K. Identification of cellular and viral factors related to anti-hepatitis C virus activity of cyclophilin inhibitor. Cancer Sci. 2009, 100, 1943-1950.

128. Puyang, X.; Poulin, D.L.; Mathy, J.E.; Anderson, L.J.; Ma, S.; Fang, Z.; Zhu, S.; Lin, K.; Fujimoto, R.; Compton, T.; et al. Mechanism of resistance of hepatitis $\mathrm{C}$ virus replicons to structurally distinct cyclophilin inhibitors. Antimicrob. Agents Chemother. 2010, 54, 1981-1987.

129. Delang, L.; Vliegen, I.; Froeyen, M.; Neyts, J. Comparative study of the genetic barriers and pathways towards resistance of selective inhibitors of hepatitis $\mathrm{C}$ virus replication. Antimicrob. Agents Chemother. 2011, 55, 4103-4113.

130. Colgan, J.; Asmal, M.; Neagu, M.; Yu, B.; Schneidkraut, J.; Lee, Y.; Sokolskaja, E.; Andreotti, A.; Luban, J. Cyclophilin A regulates TCR signal strength in CD4+ T cells via a proline-directed conformational switch in Itk. Immunity 2004, 21, 189-201.

131. Liu, X.; Zhao, Z.; Liu, W. Insights into the roles of cyclophilin A during influenza virus infection. Viruses 2013, 5, 182-191.

132. Mendu, V.; Chiu, M.; Barajas, D.; Li, Z.; Nagy, P.D. Cpr1 cyclophilin and Ess 1 parvulin prolyl isomerases interact with the tombusvirus replication protein and inhibit viral replication in yeast model host. Virology 2010, 406, 342-351.

133. Qing, M.; Yang, F.; Zhang, B.; Zou, G.; Robida, J.M.; Yuan, Z.; Tang, H.; Shi, P.Y. Cyclosporine inhibits flavivirus replication through blocking the interaction between host cyclophilins and viral NS5 protein. Antimicrob. Agents Chemother. 2009, 53, 3226-3235. 
134. Li, Y.J.; Wu, H.H.; Weng, C.H.; Chen, Y.C.; Hung, C.C.; Yang, C.W.; Wang, R.Y.; Sakamoto, N.; Tian, Y.C. Cyclophilin A and nuclear factor of activated T cells are essential in cyclosporinemediated suppression of polyomavirus BK replication. Am. J. Transplant. 2012, 12, 2348-2362.

135. De Wilde, A.H.; Li, Y.; van der Meer, Y.; Vuagniaux, G.; Lysek, R.; Fang, Y.; Snijder, E.J.; van Hemert, M.J. Cyclophilin inhibitors block arterivirus replication by interfering with viral RNA synthesis. J. Virol. 2013, 87, 1454-1464.

136. He, H.; Zhou, D.; Fan, W.; Fu, X.; Zhang, J.; Shen, Z.; Li, J.; Wu, Y. Cyclophilin A inhibits rotavirus replication by facilitating host IFN-I production. Biochem. Biophys. Res. Commun. 2012, 422, 664-669.

137. Keyes, L.R.; Bego, M.G.; Soland, M.; St Jeor, S. Cyclophilin A is required for efficient human cytomegalovirus DNA replication and reactivation. J. Gen. Virol. 2012, 93, 722-732.

138. Bose, S.; Mathur, M.; Bates, P.; Joshi, N.; Banerjee, A.K. Requirement for cyclophilin A for the replication of vesicular stomatitis virus New Jersey serotype. J. Gen. Virol. 2003, 84, 1687-1699.

139. Castro, A.P.; Carvalho, T.M.; Moussatche, N.; Damaso, C.R. Redistribution of cyclophilin A to viral factories during vaccinia virus infection and its incorporation into mature particles. J. Virol. 2003, 77, 9052-9068.

140. Chung, C.S.; Chen, C.H.; Ho, M.Y.; Huang, C.Y.; Liao, C.L.; Chang, W. Vaccinia virus proteome: Identification of proteins in vaccinia virus intracellular mature virion particles. J. Virol. 2006, 80, 2127-2140.

141. Watanabe, A.; Yoneda, M.; Ikeda, F.; Terao-Muto, Y.; Sato, H.; Kai, C. CD147/EMMPRIN acts as a functional entry receptor for measles virus on epithelial cells. J. Virol. 2010, 84, 4183-4193.

142. Bienkowska-Haba, M.; Patel, H.D.; Sapp, M. Target cell cyclophilins facilitate human papillomavirus type 16 infection. PLoS Pathog. 2009, 5, e1000524.

143. Bienkowska-Haba, M.; Williams, C.; Kim, S.M.; Garcea, R.L.; Sapp, M. Cyclophilins facilitate dissociation of the human papillomavirus type 16 capsid protein L1 from the L2/DNA complex following virus entry. J. Virol. 2012, 86, 9875-9887.

144. De Wilde, A.H.; Zevenhoven-Dobbe, J.C.; van der Meer, Y.; Thiel, V.; Narayanan, K.; Makino, S.; Snijder, E.J.; van Hemert, M.J. Cyclosporin A inhibits the replication of diverse coronaviruses. J. Gen. Virol. 2011, 92, 2542-2548.

145. Pfefferle, S.; Schopf, J.; Kogl, M.; Friedel, C.C.; Muller, M.A.; Carbajo-Lozoya, J.; Stellberger, T.; von Dall'Armi, E.; Herzog, P.; Kallies, S.; et al. The SARS-coronavirus-host interactome: Identification of cyclophilins as target for pan-coronavirus inhibitors. PLoS Pathog. 2011, 7, e1002331.

146. Favreau, D.J.; Meessen-Pinard, M.; Desforges, M.; Talbot, P.J. Human coronavirus-induced neuronal programmed cell death is cyclophilin d dependent and potentially caspase dispensable. J. Virol. 2012, 86, 81-93.

147. Xia, W.L.; Shen, Y.; Zheng, S.S. Inhibitory effect of cyclosporine A on hepatitis B virus replication in vitro and its possible mechanisms. Hepatobiliary Pancreat. Dis. Int. 2005, 4, 18-22.

148. Zhao, C.; Fang, C.Y.; Tian, X.C.; Wang, L.; Yang, P.Y.; Wen, Y.M. Proteomic analysis of hepatitis B surface antigen positive transgenic mouse liver and decrease of cyclophilin A. J. Med. Virol. 2007, 79, 1478-1484. 
149. Tian, X.; Zhao, C.; Zhu, H.; She, W.; Zhang, J.; Liu, J.; Li, L.; Zheng, S.; Wen, Y.M.; Xie, Y. Hepatitis B virus (HBV) surface antigen interacts with and promotes cyclophilin a secretion: Possible link to pathogenesis of HBV infection. J. Virol. 2010, 84, 3373-3381.

150. Ansari, I.; Allen, T; Berical, A; Stock, P.; Barin, B.; Striker, R. Phenotypic analysis of NS5A variant from liver transplant patient with increased cyclosporine susceptibility. Virology 2013, 436, 268-273.

(C) 2013 by the authors; licensee MDPI, Basel, Switzerland. This article is an open access article distributed under the terms and conditions of the Creative Commons Attribution license (http://creativecommons.org/licenses/by/3.0/). 